\title{
THE HUMAN PATHOGENS CARRIED BY THE COCKROACHES IN THE FOOD- RELATED ENVIRONMENT POTENTIALLY CAUSING A FOODBORNE DISEASES: A SYSTEMATIC REVIEW
}

\author{
Rizki Zahrotul Hayati ${ }^{1}$ and Dewi Susanna ${ }^{1}$ \\ ${ }^{1}$ Department of Environmental Health, Faculty of Public Health, Universitas Indonesia, Depok, Jawa Barat, Indonesia \\ Corresponding author: Dewi Susanna \\ Email: dsusanna@ui.ac.id
}

\begin{abstract}
Cockroaches are one of the potential vectors on spreading disease and health problems for humans by contaminating foods, ingredients, or food storage. Cause of their habit and life in an unsanitary place, they can carry human pathogens in their body and contaminated. This review aims to know the types and prevalence of human pathogens carried by cockroaches in the food-related environment and discuss the possibility of human pathogens carried by cockroaches that can cause foodborne diseases. This systematic review conforms to the PRISMA guidelines. The initial search was done from four health-related electronic databases (PubMed Central, EBSCOhost, Proquest, and Scopus) for relevant literature on pathogens that isolated from the cockroaches. There are 129 articles identified in the initial search database. After screening and eligibility process, eight articles were identified for this review. It was found that most of the cockroaches captured in/around food handling establishment and human habitation. Furthermore, around 23 species pathogens, predominantly bacteria, were identified from the cockroaches. This review showed that cockroaches carry many pathogens, which can cause severe infections in humans, such as foodborne diseases through contaminated food.
\end{abstract}

Keywords: Cockroaches; Pathogen; Food-related environment; Foodborne disease.

\section{INTRODUCTION}

Foodborne diseases commonly said as foodborne illness or food poisoning is a public health problem globally ${ }^{1}$. CDC estimates that each year roughly 48 million people (1 in 6) get sick, 128,000 are hospitalized, and 3,000 die due to foodborne disease $^{2}$. The causes of foodborne illnesses are pathogens like bacteria, viruses, parasites, and chemical substances that enter the human body through contaminated food or water ${ }^{2,3}$. One of the potential vectors which can contaminate food is cockroaches, cause they are common in many human habitations, particularly in places where food stored or handled ${ }^{4}$.

Many cockroaches are dark, dull-coloured insects and nocturnal habits ${ }^{5,6}$. They are tropical in origin, but most species live in parts of the house and other buildings where warmth, moisture, and food are adequate 6 . Cockroaches live closely related to humans, and unsanitary place ${ }^{5,7-9}$. Their habit of feeding on both human food and feces, it can potentially become a mechanical vector on spreading disease agents and health problem for a human ${ }^{7,8,10}$. American cockroaches and other cockroaches generally produce odours secretion that can affect the flavour of food. When populations are high, these secretions may result in characteristic odours in the general region of the infestation. Disease-producing organisms such as bacteria, protozoa, and viruses have been found in particular parts of their body ${ }^{9,10}$. The disease-producing organism was carried on the legs and bodies of cockroaches and deposited on food and utensils?.

Cockroaches, in pathogen mechanical transmission role known as mechanical vectors ${ }^{11-}$ ${ }^{14}$, but in some literature, they also can be biological vectors ${ }^{11,13}$. Cockroaches can transmit microorganisms and other disease agents indirectly by contaminating food or ingredients in food-producing ${ }^{15}$. They are playing a role by causing intestinal diseases or foodborne diseases, such as diarrhea, dysentery, typhoid fever, and cholera ${ }^{6}$. Pathogens were isolated from the internal body of cockroaches, either the domestic or peri-domestic environment; at least there are 32 species of bacteria ${ }^{8,9}$. Including pathogens such as Bacillus subtilis (the causative agent of conjunctivitis), Escherichia coli, and nine types of Salmonella (the agent causes diarrhea, gastroenteritis, and food poisoning); Salmonella Typhi (the agent causes typhoid fever) and four Proteus spp. i.e., agents that can infect wounds 8,9 .

This systematic review aims to know the types and prevalence of human pathogens carried by cockroaches in the food-related environment. This review also discussed the possibility of human pathogens carried by cockroaches in causing foodborne diseases. 


\section{METHODOLOGY}

\section{Search Strategy}

This systematic review conforms to the Preferred Reporting Items for Systematic Review and MetaAnalyzes (PRISMA) guidelines. Original articles searched in four online databases, including Pubmed Central (PMC), ProQuest, Scopus, and EBSCOhost using the keywords: cockroach AND pathogen AND food-related environment (kitchen OR restaurant $O R$ health care $O R$ hotel $O R$ household) in various combination.

\section{Inclusion and Exclusion}

Inclusion criteria for the article were all articles in English, published in the last ten years (20092019), academic or research articles, the contents of articles include type and species of pathogen isolated, and the method used in isolation of the pathogen, the number of cockroaches captured. Furthermore, type of study design (observational or survey or cross-sectional), location of cockroaches based on pathogen was isolated, location of cockroaches captured (kitchen, hotel, restaurant/food catering, and health care) also included in article inclusion criteria. Meanwhile, excluded articles were those using review articles, qualitative methods, experimental study, articles that do not fit with inclusion criteria above, and not open access articles.

\section{Study Selection}

The study selection carried out by three reviewers to examine the selected article and the determination of eligibility of the article to be reviewed seen from the title, abstract, and full text according to inclusion criteria.

\section{Data Extraction}

Data extracted from eligible studies included, authors, published year, country of the research conducted, design and method of research, area of research (food-related environment), type of cockroaches, location captured of the cockroaches, identification of pathogens in cockroaches, site of the cockroaches from where pathogen isolated (external or internal body), and the number of isolated human pathogens.

\section{Data Synthesis}

Data synthesis using narrative synthesis. Narrative synthesis in this review discussed the research area based on the food-related environment (kitchen, cafeteria, restaurant, health or medical center, and households), the types and the number of cockroaches trapped on the research area, the types and the number of human pathogens found on the location of human pathogens isolation and research areas, and also combining the results with other literatures.

\section{RESULTS}

A total of 129 articles were identified in the initial search databases. During the screening and eligibility process, 121 articles excluded. In detail, four articles duplicated, 112 articles excluded based on the title and abstract screening, 1 article not appropriate of study design, two articles only identify specific bacteria, and two articles do not explain the number of bacteria isolated. Of these, a final eight articles were identified for this review (Figure 1).

Of the eight eligible articles, there were conducted in various countries, including Northeast Africa (3), Western Asia (2), Central Africa (1), West Africa (1), and South Asia (1). All published articles covered the years 2012-2018. Some of the articles clearly state a cross-sectional design study, but other articles can be seen from the method and time of the study they used. The population in this study is cockroaches. Mostly, species of cockroaches were identified using standard taxonomy keys. Method of trapping cockroaches in 8 articles using sterile hand gloves, sterile test tubes, sticky traps, and food baited traps. The most common method used to isolate the pathogens is agar-plate method (i.e., blood agar, MacConkey agar, deoxycholate citrate agar, etc.) (Table 1).

The research areas of these articles belong to food-related environments such as health and medical centers such as hospitals, food handling establishments (restaurants, cafeterias, bakeries, grocery stores, food storage stores, small food processing plants, etc.), and households, including the kitchen.

Most cockroaches caught in the food handling establishments. Of these eight articles, four species of cockroaches were found that are Periplaneta americana, Blatella germanica, Blatta orientalis, and Supella longipalpa. The most species of cockroaches that were trapped is Blatella germanica $(n=3235)$ (Table 2). 


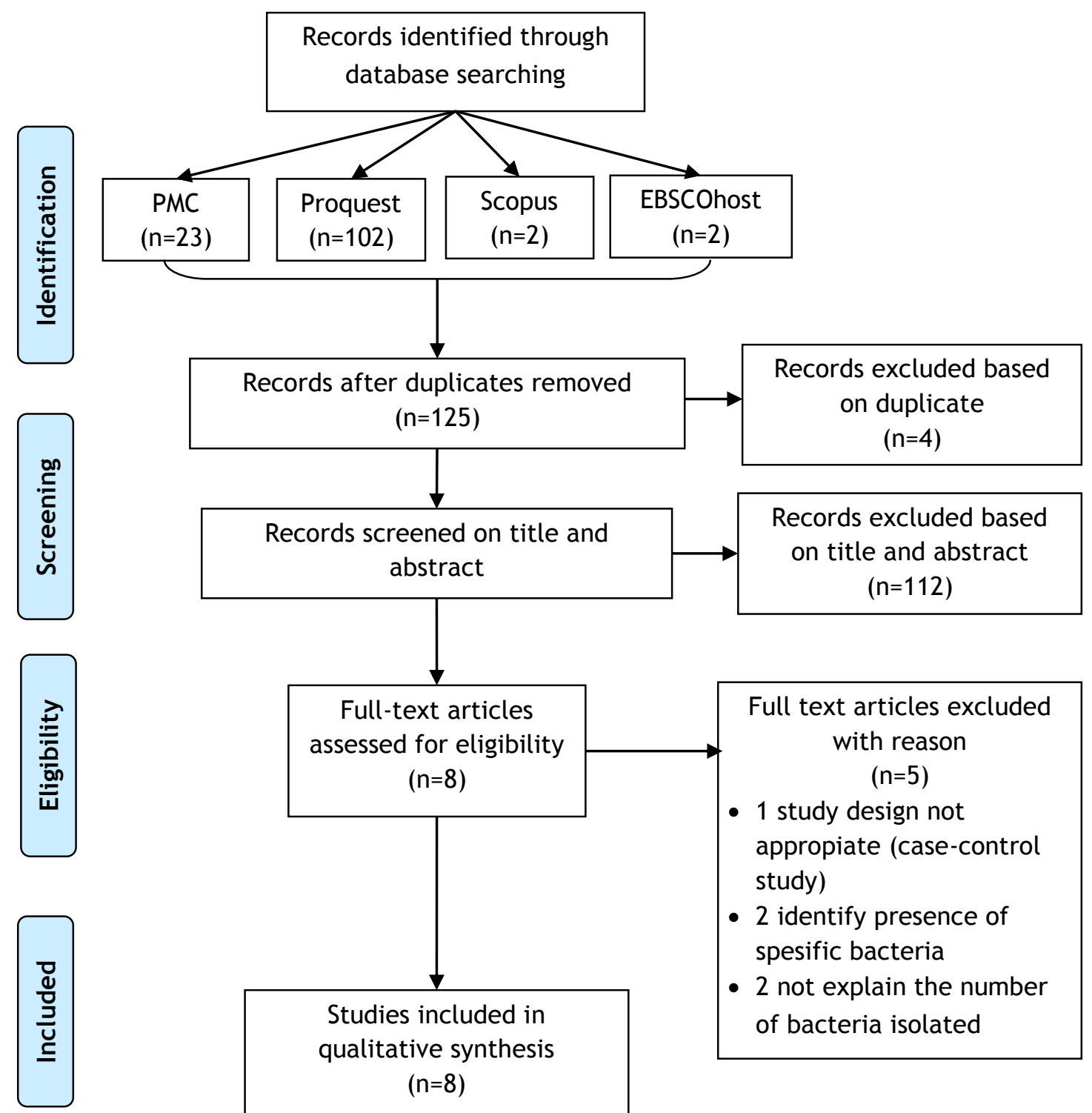

Figure 1. Flowchart of Systematic Review using PRISMA guidelines ${ }^{34}$

Pathogen isolation is carried out on the internal and external parts of the cockroaches. Most of the articles were frequently isolated from the external body surfaces of the cockroaches. There are 23 species of pathogens include parasite $(n=9)$ and bacteria $(n=14)$. Among the parasite pathogens isolated, Ascaris spp is the most frequently reported, then Trichuris spp. and Hookworm (Table 3). Among the bacterial pathogens isolated, enteric pathogens were the most frequently isolated, such as $E$. coli, Salmonella, Shigella ${ }^{23}$, Edwardsiella ${ }^{24}$, etc. $E$. coli is the most frequent species bacteria isolated in this review $(n=181)$ (Tabel 3$)$.

\section{DISCUSSION}

In this systematic review found four species of cockroaches in the various country. Blatella germanica $(n=3235)$ is the most frequently reported. Periplaneta americana $(n=821)$ was the second, followed by Blatta orientalis $(n=235)$, and Supella longipalpa $(\mathrm{n}=39)$ were the least frequent. Blatella germanica and Periplaneta Americana were found in Central, West, and Northeastern Africa while in Asia, founded in West and South Asia. Blatta orientalis found in Central and West Africa and Supella longipalpa only found in West Asia in this systematic review. 
Table 1. Articles Characteristics

\begin{tabular}{|c|c|c|c|c|}
\hline $\begin{array}{l}\text { Published } \\
\text { year }\end{array}$ & Author & Country & Design & Methods \\
\hline 2012 & $\begin{array}{l}\text { Kassiri, Hamid; } \\
\text { Kazemi, Shahnaz }^{16}\end{array}$ & Iran & $\begin{array}{l}\text { Cross- } \\
\text { sectional }\end{array}$ & $\begin{array}{l}\text { Trapping (use sterile test tubes and } \\
\text { sterile hand gloves) and laboratory test } \\
\text { (identification the human pathogens } \\
\text { use standard bacteriological } \\
\text { procedures and cultured to isolate the } \\
\text { bacteria using MacConkey agar, blood } \\
\text { agar, and deoxycholate citrate agar) }\end{array}$ \\
\hline 2014 & $\begin{array}{l}\text { Wannigama, D. } \\
\text { Leshan; Dwivedi, } \\
\text { Rishabh; Zahraei- } \\
\text { Ramazani, Alireza }{ }^{17}\end{array}$ & India & $\begin{array}{l}\text { Cross- } \\
\text { sectional }\end{array}$ & $\begin{array}{l}\text { Trapping (food-baited pitfall traps), } \\
\text { identification of cockroaches (under an } \\
\text { Olympus SZX12 Dissecting Stereo } \\
\text { Microscope), and laboratory test } \\
\text { (cultured to isolate the bacteria using } \\
\text { blood agar and MacConkey agar) }\end{array}$ \\
\hline 2014 & $\begin{array}{l}\text { Vazirianzadeh, Babak; } \\
\text { Dehghani, Rouhullah; } \\
\text { Mehdinejad, Manijeh; } \\
\text { Sharififard, Mona }{ }^{18}\end{array}$ & Iran & $\begin{array}{l}\text { Cross- } \\
\text { sectional }\end{array}$ & $\begin{array}{l}\text { Trapping, and laboratory test (cultured } \\
\text { to isolate the bacterial agents on blood } \\
\text { and MacConkey agar media) }\end{array}$ \\
\hline 2014 & $\begin{array}{l}\text { Solomon, Fithamlak; } \\
\text { Belayneh, Fanuel; } \\
\text { Kibru, Gebre; Ali, } \\
\text { Solomon }{ }^{7}\end{array}$ & Ethiopia & $\begin{array}{l}\text { Cross- } \\
\text { sectional }\end{array}$ & $\begin{array}{l}\text { Trapping (use Hoy-Hoy roach sticky } \\
\text { traps) and laboratory test (identify and } \\
\text { cultured to isolate the bacterial using } \\
\text { agar plates) }\end{array}$ \\
\hline 2016 & $\begin{array}{l}\text { Moges, Feleke; } \\
\text { Eshetie, Setegn; } \\
\text { Endris, Mengistu; } \\
\text { Huruy, Kahsay; } \\
\text { Muluye, Dagnachew; } \\
\text { Feleke, Tigist; Silassie, } \\
\text { Fisha G.; Ayalew, } \\
\text { Getenet; Nagappan, } \\
\text { Raja19 }\end{array}$ & Ethiopia & $\begin{array}{l}\text { Cross- } \\
\text { sectional }\end{array}$ & $\begin{array}{l}\text { Trapping (use sterile test tubes) and } \\
\text { laboratory test (bacterial culture } \\
\text { inoculation using MacConkey agar, } \\
\text { blood agar plate, and chocolate agar } \\
\text { plate) }\end{array}$ \\
\hline 2016 & $\begin{array}{l}\text { Oyeyemi, Oyetunde T.; } \\
\text { Agbaje, Mariam O.; } \\
\text { Okelue, Uchechi B. }{ }^{20}\end{array}$ & Nigeria & $\begin{array}{l}\text { Cross- } \\
\text { sectional }\end{array}$ & $\begin{array}{l}\text { Trapping and laboratory test using } \\
\text { (parasite isolation) }\end{array}$ \\
\hline 2017 & $\begin{array}{l}\text { Tatang, R. J. Atiokeng; } \\
\text { Tsila, H. G.; Poné, J. } \\
\text { Wabo }^{21}\end{array}$ & Cameroon & $\begin{array}{l}\text { Cross- } \\
\text { sectional }\end{array}$ & $\begin{array}{l}\text { Trapping (use sterile hand gloves) and } \\
\text { laboratory test (parasitological } \\
\text { analyses) }\end{array}$ \\
\hline 2018 & $\begin{array}{l}\text { Solomon, Fithamlak; } \\
\text { Kibru, Gebre; Ali, } \\
\text { Solomon'22 }\end{array}$ & Ethiopia & $\begin{array}{l}\text { Cross- } \\
\text { sectional }\end{array}$ & $\begin{array}{l}\text { Trapping (use Hoy-Hoy roach sticky } \\
\text { traps) and laboratory test (identify and } \\
\text { cultured to isolate the bacterial using } \\
\text { agar plates) }\end{array}$ \\
\hline
\end{tabular}

Table 2: Prevalence of cockroaches captured, including the area of cockroaches collection and species

\begin{tabular}{|c|c|c|c|c|c|}
\hline \multirow[b]{2}{*}{$\begin{array}{l}\text { Area of cockroaches } \\
\text { collection }\end{array}$} & \multicolumn{4}{|c|}{ Cockroaches species } & \multirow[b]{2}{*}{ Total } \\
\hline & $\begin{array}{c}\text { Periplaneta } \\
\text { americana }\end{array}$ & $\begin{array}{l}\text { Blatella } \\
\text { germanica }\end{array}$ & $\begin{array}{c}\text { Blatta } \\
\text { orientalis }\end{array}$ & $\begin{array}{c}\text { Supella } \\
\text { longipalpa }\end{array}$ & \\
\hline Health and medical center* & 103 & - & - & - & \\
\hline $\begin{array}{l}\text { Food handling } \\
\text { establishments }\end{array}$ & 78 & 3027 & - & - & 3105 \\
\hline Household ${ }^{* * *}$ & 640 & 208 & 235 & 39 & 1122 \\
\hline Total & 821 & 3235 & 235 & 39 & 4330 \\
\hline
\end{tabular}

* Health and medical center such as the hospital.

${ }^{* *}$ Food handling establishments (FHE), including restaurant, cafeteria, canteen, grocery store, food storage store, and small food processing plant.

${ }^{* * *}$ Household, including toilet, kitchen, parlour, and bedroom.

The presence and number of cockroaches usually seen from the habitat of each cockroach. Blatella germanica is the important pest of residential, commercial, office, and industrial places ${ }^{25}$. These cockroaches often in human settlements and enter through boxes containing food, vegetables, 
drinks, or enter together through furniture materials or other tools. They are generally located in the kitchen but also found in bathroom ${ }^{26}$. According to their habit, in this review, Blattella germanica $(n=3235)$ is also found in a household (including kitchen and toilet) and food handling establishment, especially in the storage room, small processing plants, and restaurants ${ }^{17}$.

Periplaneta americana is the species that often becomes abundant in city dumps and is most common in the basements and steam tunnels of restaurants, bakeries, food-processing facilities, and grocery stores. Their habit matches the reviews, those cockroaches found in households, hospitals, and food-related environments. Another case with Blatta orientalis, they found in humid and cold places such as under rotted leaves or rocks, flowers, and various garden plants, in the trash and other impurities, and water drainage systems. Sometimes, they will move to human residential buildings ${ }^{27}$. In this review, the presence of Blatta orientalis influenced by environmental conditions around the study site. Blatta orientalis found in unsanitary places such as no toilet facilities, and there are public waste and refuse dumpsites nearby community houses ${ }^{20,21}$.

Other species, Supella longipalpa in this review, only found in Iran, West Asia, and they located in the kitchen of houses ${ }^{18}$. According to their habit, they are commonly found in homes, apartments, hotels, and hospitals and less frequently in stores, restaurants, and kitchens. They prefer to live in and around heat-producing electric appliances ${ }^{28}$.

This systematic review revealed at least 23 pathogen species that have been isolated from the cockroaches. Bacterial pathogens $(n=14)$ were by far the most frequently reported, followed by parasites $(n=9)$. Differences in the isolation rate of these pathogens could be related to the method they used. Most of the articles reviewed used standard cultural methods for the isolation of pathogens, which may have directly lead to the outcome of bacterial pathogens.

Culture-based techniques have been considered the gold standard of pathogen detection. However, some organisms may not be easily detectable by conventional culture methods used in most laboratories due to many factors ${ }^{29}$. Therefore, more advanced techniques including Polymerase Chain Reaction (PCR), which can help in rapid detection, detect bacteria that cannot be grown or are slow-growing in culture methods, and PCR based testing would be more sensitive than culture method ${ }^{29,30}$.
Most of the pathogens were isolated in the external body of cockroaches. Only five articles carried out bacterial isolation on the external and internal bodies of cockroaches. In the literature, the occurrence of Gram-negative species (Salmonella spp., E. coli, etc.) on the surface was lower than in the tract, compared to Grampositive (S. aureus, B. cereus, etc.) species that showed low density in both body parts. ${ }^{31}$ However, in this article, the differences number of pathogens in the external and internal body not significant. Only a few Gram-negative species show a higher number in the internal body. For example, a study in Ethiopia show that the number of infestation Salmonella spp. in the internal body $(n=16)$ was higher than the external body $(n=6)$. But, other Gram-negative species do not show the differences ${ }^{22}$.

The highest number of parasite species is Ascaris spp. $(\mathrm{n}=419)$. The second one is the Trichuris spp. $(n=139)$, followed by hookworm $(n=124)$, Capillaria spp. $(\mathrm{n}=77)$, and the fewest is Entamoeba histolytica $(\mathrm{n}=1)$ (Table 3 ). All of the parasite species were found in households, including the kitchen, toilet, parlour, bedroom, and bathroom 20,21 . The presence of those parasites in cockroaches found in households can potentially contaminating food and food utensils. Then it can be causing foodborne diseases, such as amoebiasis and ascariasis. Amoebiasis caused by Entamoeba histolytica then Ascariasis by Ascaris spp. was the leading parasitic cause of illness due to contaminated food ${ }^{32}$. They can cause illness when ingested of infective eggs from soil contaminated with feces or of contaminated vegetables and water, inadequate waste disposal, and poor hygiene in food handling ${ }^{32,33}$.

The highest number of bacteria species is E.coli $(\mathrm{n}=181)$. Next, the second one Klebsiella pneumonia $(\mathrm{n}=143)$ and other Klebsiella spp. $(n=135)$, followed by CNS (Coagulase Negative Staphylococcus) ( $\mathrm{n}=89)$, Enterobacter spp. $(n=152)$, and the fewest is Salmonella C1 $(n=1)$ (Table 3). All of the bacteria species were found in households (including kitchen, toilet, parlour, bedroom, and bathroom), health and medical center, and food handling establishment ${ }^{20,21}$. The presence of those bacteria in cockroaches found in that place can occur foodborne disease, for example, lower gastrointestinal tract symptoms (abdominal cramps, diarrhea) ${ }^{32}$. Because of cockroach habits such as living in unclean places and eating human food and feces ${ }^{7,8}, E$. coli contamination can occur due to food contaminated with feces carried by cockroaches $^{32}$. 
Tabel 3. Human pathogens genera and species that isolated from cockroaches, including the area of cockroaches and the location of isolation

\begin{tabular}{|c|c|c|c|c|c|c|c|}
\hline \multicolumn{2}{|c|}{ Human pathogens } & \multicolumn{2}{|c|}{$\begin{array}{l}\text { Location and } \\
\text { number of } \\
\text { isolation }\end{array}$} & \multirow{2}{*}{$\begin{array}{l}\text { Total of } \\
\text { pathogens } \\
\text { isolated }\end{array}$} & \multirow[t]{2}{*}{ Area of cockroaches collection } & \multirow[t]{2}{*}{ Add inform. } & \multirow[t]{2}{*}{ Ref. } \\
\hline $\begin{array}{c}\text { Types of } \\
\text { genera }\end{array}$ & Types of Species & External & Internal & & & & \\
\hline \multicolumn{8}{|c|}{ Bacteria genera and species } \\
\hline \multirow[t]{7}{*}{ Salmonella } & Salmonella para $A$ & 2 & 3 & 5 & Household (kitchen) & $\begin{array}{l}\text { Internal body (alimentary } \\
\text { duct) }\end{array}$ & 18 \\
\hline & Salmonella B & 3 & 6 & 9 & FHE (restaurant and cafeteria) & Internal body (gut) & 7 \\
\hline & Salmonella D & 2 & 3 & 5 & FHE (restaurant and cafeteria) & Internal body (gut) & 7 \\
\hline & Salmonella C1 & 0 & 1 & 1 & FHE (restaurant and cafeteria) & Internal body (gut) & 7 \\
\hline & Salmonella E & 0 & 3 & 3 & FHE (restaurant and cafeteria) & Internal body (gut) & 7 \\
\hline & Salmonella NG & 1 & 3 & 4 & FHE (restaurant and cafeteria) & Internal body (gut) & 7 \\
\hline & Salmonella spp. & 27 & 19 & 46 & $\begin{array}{l}\text { Household (kitchen, living room, } \\
\text { toilet, and bedroom); FHE (canteen, } \\
\text { bakeries, grocery store, food } \\
\text { storage store, small food processing } \\
\text { plant, restaurant }^{17} \text {, and cafeteria }{ }^{22} \text { ); } \\
\text { Health and medical center } \\
\text { (hospital) }\end{array}$ & Internal body (gut) ${ }^{19,22}$ & $17,19,22$ \\
\hline Escherichia & E. coli & 123 & 58 & 181 & 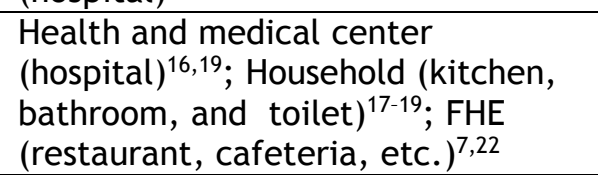 & $\begin{array}{l}\text { Internal body }\left(\text { gut }^{7,19,22},\right. \\
\left.\text { alimentary duct }{ }^{18}\right)\end{array}$ & $7,16-19,22$ \\
\hline \multirow[t]{3}{*}{ Bacillus } & B. cereus & 24 & 27 & 51 & $\begin{array}{l}\text { Household (kitchen) }{ }^{18} \text {; FHE } \\
\text { (restaurant and cafeteria) }^{7}\end{array}$ & $\begin{array}{l}\text { Internal body }\left(\text { gut }^{7} \text {, }\right. \\
\text { alimentary duct }{ }^{18} \text { ) }\end{array}$ & 7,18 \\
\hline & B. subtilis & 4 & 12 & 16 & $\begin{array}{l}\text { Household (kitchen) })^{18} ; \mathrm{FHE} \\
\text { (restaurant and cafeteria) }^{7}\end{array}$ & $\begin{array}{l}\text { Internal body }\left(\mathrm{gut}^{7},\right. \\
\left.\text { alimentary } \mathrm{duct}^{18}\right)\end{array}$ & 7,18 \\
\hline & Bacillus spp. & 25 & 41 & 66 & $\begin{array}{l}\text { Health and medical center }{ }^{16} ; \mathrm{FHE} \\
\text { (restaurant and cafeteria) }^{7}\end{array}$ & Internal body (gut) ${ }^{7}$ & 7,16 \\
\hline \multirow[t]{2}{*}{ Shigella } & S.flexneri & 4 & 2 & 6 & FHE (restaurant and cafeteria) & Internal body (gut) ${ }^{7,22}$ & 7,22 \\
\hline & Shigella spp. & 8 & 5 & 13 & $\begin{array}{l}\text { Healthand medical center (hospital); } \\
\text { Household (kitchen, bathroom, } \\
\text { toilet) }\end{array}$ & Internal body (gut) & 19 \\
\hline \multirow[t]{2}{*}{ Enterobacter } & E. aerogenes & 23 & 3 & 26 & $\begin{array}{l}\text { Household (kitchen }{ }^{18} \text {, living room, } \\
\text { toilet, and bedroom) }{ }^{17} ; \mathrm{FHE}^{17}\end{array}$ & $\begin{array}{l}\text { Internal body (alimentary } \\
\text { duct) }{ }^{18}\end{array}$ & 17,18 \\
\hline & E. cloacae & 26 & 3 & 29 & $\begin{array}{l}\text { Household (kitchen }{ }^{18} \text {, living room, } \\
\text { toilet, and bedroom) })^{17} ; \mathrm{FHE}^{17}\end{array}$ & $\begin{array}{l}\text { Internal body (alimentary } \\
\text { duct) }\end{array}$ & 17,18 \\
\hline
\end{tabular}




\begin{tabular}{|c|c|c|c|c|c|c|c|}
\hline \multicolumn{2}{|c|}{ Human pathogens } & \multicolumn{2}{|c|}{$\begin{array}{l}\text { Location and } \\
\text { number of } \\
\text { isolation }\end{array}$} & \multirow{2}{*}{$\begin{array}{l}\text { Total of } \\
\text { pathogens } \\
\text { isolated }\end{array}$} & \multirow[t]{2}{*}{ Area of cockroaches collection } & \multirow[t]{2}{*}{ Add inform. } & \multirow[t]{2}{*}{ Ref. } \\
\hline $\begin{array}{l}\text { Types of } \\
\text { genera }\end{array}$ & Types of Species & External & Internal & & & & \\
\hline & E. agglomerans & 9 & 9 & 18 & Household (kitchen) & $\begin{array}{l}\text { Internal body (alimentary } \\
\text { duct) }\end{array}$ & 18 \\
\hline & Enterobacter spp. & 50 & 30 & 80 & $\begin{array}{l}\text { FHE (restaurant, cafeteria }{ }^{7}, ; \\
\text { Hospital }^{16,19} ; \text { Household (kitchen, } \\
\text { bathroom, and toilet) }\end{array}$ & Internal body (gut) 7,19 & $7,16,19$ \\
\hline \multirow[t]{3}{*}{ Klebsiella } & K. pneumoniae & 96 & 47 & 143 & $\begin{array}{l}\text { FHE (restaurant and cafeteria }{ }^{7} \text {, } \\
\text { canteen, bakeries, grocery store, } \\
\text { food storage store, small food } \\
\text { processing plant })^{17} \text {; Household } \\
\text { (kitchen }^{18} \text {, living room, toilet, and } \\
\text { bedroom })^{17} \text {; Health and medical } \\
\text { center (hospital) }\end{array}$ & $\begin{array}{l}\text { Internal body (gut) })^{7,19} ; \\
\text { Internal body (alimentary } \\
\text { duct) }{ }^{18}\end{array}$ & $7,17-19$ \\
\hline & K. oxytoca & 1 & 2 & 3 & Household (kitchen) $)^{18}$ & & 18 \\
\hline & Klebsiella spp. & 90 & 45 & 135 & $\begin{array}{l}\text { FHE (restaurant and cafeteria) } \\
\text { Health and medical center }{ }^{16} ; \\
\text { Household } \\
\text { (kitchen, bathroom, and toilet) }^{19}\end{array}$ & Internal body (gut) $)^{7,19}$ & $7,16,19$ \\
\hline \multirow[t]{3}{*}{ Staphylococcus } & S. aureus & 22 & 14 & 36 & $\begin{array}{l}\text { Health and medical center } \\
\text { (hospital) }^{19} ; \text { Household }\left(\text { kitchen }^{18} \text {, }\right. \\
\text { bathroom, and toilet) })^{19} ; \mathrm{FHE} \\
\text { (restaurant and cafeteria) }^{22}\end{array}$ & $\begin{array}{l}\text { Internal body (gut) })^{7,19,22} ; \\
\text { Internal body (alimentary } \\
\text { duct) }{ }^{18}\end{array}$ & $7,18,19,22$ \\
\hline & $\begin{array}{l}\text { CNS (Coagulase } \\
\text { Negative } \\
\text { Staphylococci) }\end{array}$ & 41 & 48 & 89 & $\begin{array}{l}\text { Health and medical center } \\
\text { (hospital) }^{19} ; \text { Household } \\
\text { (kitchen }^{18} \text {, bathroom, and toilet) }{ }^{19} ; \\
\text { FHE (restaurant and cafeteria) }\end{array}$ & $\begin{array}{l}\text { Internal body }\left(\mathrm{gut}^{7,19} \text {, }\right. \\
\left.\text { alimentary duct }{ }^{18}\right)\end{array}$ & $7,18,19$ \\
\hline & Staphylococcus spp. & 18 & - & 18 & Health and medical center & & 16 \\
\hline \multirow[t]{2}{*}{ Serratia } & S. marcescens & 13 & 10 & 23 & $\begin{array}{l}\text { FHE (restaurant and cafeteria) } \\
\text { Household } \text { (kitchen }^{18}\end{array}$ & $\begin{array}{l}\text { Internal body (gut } \\
\text { alimentary duct }\end{array}$ & 7,18 \\
\hline & Serratia spp. & 13 & 2 & 15 & $\begin{array}{l}\text { Health and medical center }{ }^{16} \\
\text { (hospital }^{19} \text { ); Household (kitchen, } \\
\text { bathroom, and toilet) })^{19}\end{array}$ & Internal body (gut) ${ }^{19}$ & 16,19 \\
\hline Pseudomonas & P. aeruginosa & 32 & - & 32 & $\begin{array}{l}\text { Household (kitchen, living room, } \\
\text { toilet, and bedroom })^{17} ; \text { Food } \\
\text { handling establishment (canteen, } \\
\text { bakeries, grocery store, food }\end{array}$ & & 7,17 \\
\hline
\end{tabular}




\begin{tabular}{|c|c|c|c|c|c|c|c|}
\hline \multicolumn{2}{|c|}{ Human pathogens } & \multicolumn{2}{|c|}{$\begin{array}{l}\text { Location and } \\
\text { number of } \\
\text { isolation }\end{array}$} & \multirow{2}{*}{$\begin{array}{l}\text { Total of } \\
\text { pathogens } \\
\text { isolated }\end{array}$} & \multirow[t]{2}{*}{ Area of cockroaches collection } & \multirow[t]{2}{*}{ Add inform. } & \multirow[t]{2}{*}{ Ref. } \\
\hline $\begin{array}{l}\text { Types of } \\
\text { genera }\end{array}$ & Types of Species & External & Internal & & & & \\
\hline & & & & & $\begin{array}{l}\text { storage store, small food processing } \\
\text { plant }^{17} \text {, restaurant and cafeteria) }{ }^{7}\end{array}$ & & \\
\hline & Pseudomonas spp. & 27 & - & 27 & Health and medical center ${ }^{16}$ & & 16 \\
\hline \multirow[t]{3}{*}{ Proteus } & P. mirabilis & 35 & 21 & 56 & $\begin{array}{l}\text { FHE (restaurant and cafeteria }{ }^{7}, \\
\text { canteen, bakeries, grocery store, } \\
\text { food storage store, small food } \\
\text { processing plant })^{17} \text {; Household } \\
\text { (kitchen }^{18} \text {, living room, toilet, and } \\
\text { bedroom) }^{17}\end{array}$ & $\begin{array}{l}\text { Internal body }\left(\text { gut }^{7} \text {, }\right. \\
\text { alimentary } \text { duct }^{18} \text { ) }\end{array}$ & $7,17,18$ \\
\hline & P. vulgaris & 9 & 16 & 25 & $\begin{array}{l}\text { FHE (restaurant and cafeteria) } \\
\text { Household } \text { (kitchen }^{18}\end{array}$ & $\begin{array}{l}\text { Internal body (gut } \\
\text { alimentary duct }\end{array}$ & 7,18 \\
\hline & Proteus spp. & 3 & 1 & 4 & $\begin{array}{l}\text { Health and medical center }{ }^{16} ; \\
\text { Household (kitchen, bathroom, and } \\
\text { toilet) }{ }^{20}\end{array}$ & Internal body (gut) ${ }^{20}$ & 16,20 \\
\hline \multirow[t]{3}{*}{ Citrobacter } & C. freundii & 36 & 24 & 60 & $\begin{array}{l}\text { Household (kitchen }{ }^{18} \text {, living room, } \\
\text { toilet, and bedroom) })^{17} ; \text { Food } \\
\text { handling establishment (canteen, } \\
\text { bakeries, grocery store, food } \\
\text { storage store, small food processing } \\
\text { plant }^{17} \text {, restaurant and cafeteria }{ }^{7} \text { ) }\end{array}$ & $\begin{array}{l}\text { Internal body (alimentary } \\
\text { duct }^{18} \text {, gut }{ }^{7} \text { ) }\end{array}$ & $7,17,18$ \\
\hline & C. diversus & 7 & 8 & 15 & FHE (Restaurant and cafeteria) & Internal body (gut) & 7 \\
\hline & Citrobacter spp. & 15 & 12 & 27 & $\begin{array}{l}\text { Health and medical center } \\
\text { (hospital) })^{19} \text {; Household (kitchen, } \\
\text { bathroom, and toilet) }\end{array}$ & Internal body (gut) & 19 \\
\hline Providencia & Providencia spp. & 8 & 8 & 16 & $\begin{array}{l}\text { Health and medical center } \\
\text { (hospital); Household (kitchen, } \\
\text { bathroom, and toilet) }\end{array}$ & Internal body (gut) & 19 \\
\hline Streptococcus & Streptococcus spp. & 11 & - & 11 & Health and medical center & & 16 \\
\hline Edwardsiella & Edwardsiella spp. & 10 & 5 & 15 & FHE (Restaurant and cafeteria) & Internal body (gut) & 7 \\
\hline \multicolumn{8}{|c|}{ Parasite genera and species } \\
\hline Ascaris & A. lumbricoides & 68 & - & 68 & $\begin{array}{l}\text { Household (toilet, kitchen, parlour, } \\
\text { and bedroom) }\end{array}$ & & 20 \\
\hline
\end{tabular}




\begin{tabular}{|c|c|c|c|c|c|c|c|}
\hline \multicolumn{2}{|c|}{ Human pathogens } & \multicolumn{2}{|c|}{$\begin{array}{l}\text { Location and } \\
\text { number of } \\
\text { isolation }\end{array}$} & \multirow{2}{*}{$\begin{array}{l}\text { Total of } \\
\text { pathogens } \\
\text { isolated }\end{array}$} & \multirow[t]{2}{*}{ Area of cockroaches collection } & \multirow[t]{2}{*}{ Add inform. } & \multirow[t]{2}{*}{ Ref. } \\
\hline $\begin{array}{l}\text { Types of } \\
\text { genera }\end{array}$ & Types of Species & External & Internal & & & & \\
\hline & Ascaris spp. & 240 & 179 & 419 & Household (toilet, kitchen, houses) & $\begin{array}{l}\text { Internal body (abdomen, } \\
\text { gut, other internal organs, } \\
\text { and gastrointestinal tract) }\end{array}$ & 21 \\
\hline \multirow[t]{2}{*}{ Trichuris } & T. truchiuria & 27 & - & 27 & $\begin{array}{l}\text { Household (toilet, kitchen, parlour, } \\
\text { and bedroom) }\end{array}$ & & 20 \\
\hline & Trichuris spp. & 81 & 58 & 139 & Household (toilet, kitchen, houses) & $\begin{array}{l}\text { Internal body (abdomen, } \\
\text { gut, other internal organs, } \\
\text { and gastrointestinal tract) }\end{array}$ & 21 \\
\hline Capillaria & Capillaria spp. & 46 & 31 & 77 & Household (toilet, kitchen, houses) & $\begin{array}{l}\text { Internal body (abdomen, } \\
\text { gut, other internal organs, } \\
\text { and gastrointestinal tract) }\end{array}$ & 21 \\
\hline Toxocara & Toxocara spp. & 38 & 28 & 66 & Household (toilet, kitchen, houses) & $\begin{array}{l}\text { Internal body (abdomen, } \\
\text { gut, other internal organs, } \\
\text { and gastrointestinal tract) }\end{array}$ & 21 \\
\hline Hookworm & $\begin{array}{l}\text { Ancylostoma } \\
\text { duodenale/Necator } \\
\text { americanus }\end{array}$ & 112 & 12 & 124 & $\begin{array}{l}\text { Household (toilet, kitchen, parlour, } \\
\text { and bedroom) }\end{array}$ & $\begin{array}{l}\text { Internal body (abdomen, } \\
\text { gut, other internal organs, } \\
\text { and gastrointestinal tract) }\end{array}$ & 20,21 \\
\hline Eimeria & Eimeria spp. & 23 & 17 & 40 & Household (toilet, kitchen, houses) & $\begin{array}{l}\text { Internal body (abdomen, } \\
\text { gut, other internal organs, } \\
\text { and gastrointestinal tract) }\end{array}$ & 21 \\
\hline Enterobius & E. vermicularis & 20 & - & 20 & $\begin{array}{l}\text { Household (toilet, kitchen, parlour, } \\
\text { and bedroom) }\end{array}$ & & 20 \\
\hline Entamoeba & E. histolytica & 1 & - & 1 & $\begin{array}{l}\text { Household (toilet, kitchen, parlour, } \\
\text { and bedroom) }\end{array}$ & & 20 \\
\hline Taenia & Taenia spp. & 53 & - & 53 & $\begin{array}{l}\text { Household (toilet, kitchen, parlour, } \\
\text { and bedroom) }\end{array}$ & & 20 \\
\hline
\end{tabular}




\section{CONCLUSION}

This review showed that E. coli and Ascaris spp. were the bacteria and parasite species mostly found in cockroaches, respectively. Cockroaches are the vectors of foodborne diseases by contaminating the human food or utensils according to their habit. However, more studies on identifying new pathogens in cockroaches and the risk of causing foodborne disease are required for further study.

\section{CONFLICT OF INTEREST}

There is no conflict of interest.

\section{ACKNOWLEDGMENT}

The authors would like to thank the Directorate of Research and Community Engagement through Indexed International Publication for Student's Final Project grant for financial support.

\section{REFERENCES}

1. Centers for Disease Control and Prevention. Foodborne Diseases [Internet]. CDC.gov. 2017 [cited 2019 Jul 19]. Available from: https://www.cdc.gov/dotw/foodborne/

2. National Center for Emerging and Zoonotic Infectious Diseases, Centers for Disease Control and Prevention. Foodborne Diseases [Internet]. CDC.gov. 2017 [cited 2019 Jul 19]. Available from: https://www.cdc.gov/dotw/foodborne/

3. WHO. Food Safety [Internet]. WHO Website. 2019 [cited 2019 Jul 19]. Available from: https://www.who.int/news-room/factsheets/detail/food-safety

4. Donkor ES. Nosocomial Pathogens: An InDepth Analysis of the Vectorial Potential of Cockroaches. Trop Med Infect Dis. 2019;4(1):14.

5. Bell WJ, Roth LM, Nalepa CA. Cockroaches: ecology, behavior, and natural history. The Johns Hopkins University Press; 2007.

6. WHO. Cockroaches. In WHO Library Cataloguing in Publication Data; p. 288301. Available from: https://www.who.int/water_sanitation_h ealth/resources/vector288to301.pdf

7. Solomon F, Belayneh F, Kibru G, Ali S. Vector potential of blattella germanica (L.) (Dictyoptera: Blattidae) for medically important bacteria at food handling establishments in Jimma town, Southwest Ethiopia. Biomed Res Int [Internet]. 2016 [cited 2019 Apr 4];2016:3490906. Available from:

http://www.ncbi.nlm.nih.gov/pubmed/2 7294115

8. Brenner RJ, Kramer RD. Cockroaches (Blattaria). In: Medical and Veterinary Entomology [Internet]. 3rd ed. Elsevier; 2019 [cited 2019 Apr 6]. p. 61-77. Available from:

https: / / linkinghub.elsevier.com/retrieve/ pii/B9780128140437000066

9. Jacobs SB. American cockroaches. Coll Agric Sci. 2013;

10. Cochran DG. Cockroaches - Their Biology, Distribution and Control [Internet]. Vol. 3. WHO; 1999 [cited 2019 Jul 15]. p. 1-83. Available from: https://www.who.int/whopes/resources/ who_cds_cpc_whopes_99.3/en/

11. Malik K, Jamil A, Arshad A. Study of Pathogenic Microorganisms in the External Body Parts of American Cockroach (Periplaneta americana) Collected from different Kitchens. IOSR J Pharm Biol Sci [Internet]. 2013 [cited 2019 Apr 4];7(6):458. Available from: http: / /www.iosrjournals.org/iosrjpbs/papers/Vol7issue6/10764548.pdf?id=7390

12. Graczyk TK, Knight R, Tamang L. Mechanical transmission of human protozoan parasites by insects. Clin Microbiol Rev [Internet]. 2005 Jan [cited 2020 Jun 12];18(1):128-32. Available from: https://pubmed.ncbi.nlm.nih.gov/156538 221

13. Memona H, Manzoor F, Riaz S. Species Diversity and Distributional Pattern of Cockroaches in Lahore, Pakistan. J Arthropod Borne Dis [Internet]. 2017 [cited 2019 Sep 21];11(June):249-59. Available from:

http://jad.tums.ac.ir/index.php/jad/arti cle/download/559/334

14. Mat Yusof A. Identification of Cockroaches as Mechanical Vector for Parasitic Infections and Infestations in Kuantan, Malaysia. J Entomol [Internet]. 2018 Mar 1 [cited 2019 Apr 4];15(3):143-8. Available from:

http://www.scialert.net/abstract/?doi=je .2018.143.148

15. PAHO, FAO. Food Handlers Manual. Washington, DC: PAHO; 2017.

16. Kassiri H, Kazemi S. Cockroaches [periplaneta americana (L.), dictyoptera; blattidae] as carriers of bacterial 
pathogens, khorramshahr County, Iran. Jundishapur J Microbiol [Internet]. 2012 [cited 2019 Jul 15];5(1):320-2. Available from:

https: / / search.proquest.com/docview/92 5792297/80752F2DB61F46E4PQ/1?account id $=17242$

17. Wannigama DL, Dwivedi R, ZahraeiRamazani A. Prevalence and antibiotic resistance of gram-negative pathogenic bacteria species isolated from periplaneta americana and blattella germanica in Varanasi, India. J Arthropod Borne Dis [Internet]. 2014 [cited 2019 Jul 15];8(1):10-20. Available from: https: / /search.proquest.com/docview/14 76493040/B64103A860904F86PQ/1?accoun tid $=17242$

18. Vazirianzadeh B, Dehghani R, Mehdinejad M, Sharififard M. The First Report of Drug Resistant Bacteria Isolated from the Brown-Banded. J Arthropod Borne Dis [Internet]. 2014 [cited 2019 Jul 15];8(June):53-9. Available from: https://search.proquest.com/docview/14 76493286/29EFC31882064533PQ/1?accoun tid $=17242$

19. Moges F, Eshetie S, Endris M, Huruy K, Muluye D, Feleke T, et al. Cockroaches as a Source of High Bacterial Pathogens with Multidrug Resistant Strains in Gondar Town, Ethiopia. Biomed Res Int [Internet]. 2016 [cited 2019 Jul 15];2016. Available from:

https: / / www.ncbi.nlm.nih.gov/pmc/artic les/PMC4909895/

20. Oyeyemi OT, Agbaje MO, Okelue UB. Foodborne human parasitic pathogens associated with household cockroaches and houseflies in Nigeria. Parasite Epidemiol Control [Internet]. $2016 \mathrm{Mar}$ [cited 2019 Apr 4];1(1):10-3. Available from:

http://dx.doi.org/10.1016/j.parepi.2015. 10.001

21. Tatang RJA, Tsila HG, Poné JW. Medically Important Parasites Carried by Cockroaches in Melong Subdivision, Littoral, Cameroon. J Parasitol Res [Internet]. 2017 [cited 2019 Jun 17];2017:1-8. Available from: https: //www.ncbi.nlm.nih.gov/pubmed/2 8912965

22. Solomon F, Kibru G, Ali S. Multidrugresistant pattern of food borne illness associated bacteria isolated from cockroaches in meal serving facilities, Jimma, Ethiopia. Afr Health Sci [Internet]. 2018 [cited 2019 Jul 15];18(1):32-40.
Available

from:

https://www.ncbi.nlm.nih.gov/pmc/artic les/PMC6016973/

23. Kebede A, Aragie $\mathrm{S}$, Shimelis $\mathrm{T}$. The common enteric bacterial pathogens and their antimicrobial susceptibility pattern among HIV-infected individuals attending the antiretroviral therapy clinic of Hawassa university hospital, southern Ethiopia. Antimicrob Resist Infect Control [Internet]. 2017 [cited 2020 Jun 11];6:128. Available from: https://www.ncbi.nlm.nih.gov/pmc/artic les/PMC5741923/\#: :text=Enteric

bacterial pathogens such as,patients \%5B2\%2C 3\%5D.

24. Hirai $Y$, Tago SA, Ainoda $Y$, Fujita $T$, Kikuchi K. dwardsiella tarda bacteremia. A rare but fatal water- and foodborne infection: Review of the literature and clinical cases from a single centre. Can J Infect Dis Med Microbiol = J Can des Mal Infect la Microbiol medicale [Internet]. 2015 [cited 2020 Jun 11];26(6):313-318. Available from: https: / /www.ncbi.nlm.nih.gov/pmc/artic les/PMC4692300/pdf/jidmm-26-313.pdf

25. Nasirian H. An overview of German cockroach, Blattella germanica, studies conducted in Iran. Pakistan J Biol Sci [Internet]. 2010 [cited 2019 Aug 1];13(22):1077-84. Available from: https: / /www.researchgate.net/publicatio n/49829109_An_Overview_of_German_Co ckroach_Blattella_germanica_Studies_Con ducted_in_Iran/link/09e4150e03c7e477fc 000000/download

26. Hadi UK. Lipas atau Kecoak Jerman, Blatella germanica [Internet]. 2011 [cited 2018 Aug 1]. Available from: http:/ / upikke.staff.ipb.ac.id/files/2011/ 05/Lipas-Jerman.pdf

27. Hadi UK. Lipas atau Kecoak Oriental, Blatta orientalis [Internet]. 2011 [cited 2019 Aug 1]. Available from: http:/ / upikke.staff.ipb.ac.id/files/2011/ 06/Lipas-Oriental.pdf

28. Nasirian H. New aspects about Supella longipalpa (Blattaria: Blattellidae). Asian Pac J Trop Biomed [Internet]. 2016 [cited 2019 Aug 1];6(12):1065-75. Available from: http://dx.doi.org/10.1016/j.apjtb.2016.0 8.017

29. Abayasekara LM, Perera J, Udunuwara NA, Liyanage DS, et al. detection of bacterial pathogens from clinical specimens using conventional 
microbial culture and $16 \mathrm{~S}$ metagenomics: A comparative study. BMC Infect Dis [Internet]. 2017 [cited 2018 Aug 2];17(1):1-11. Available from: https://www.ncbi.nlm.nih.gov/pmc/artic les/PMC5606128/pdf/12879_2017_Article _2727.pdf

30. Kher S. Isolation and Identification of Bacteria. 2016.

31. Menasria T, Moussa F, El-Hamza S, Tine S, Megri R, Chenchouni $\mathrm{H}$. Bacterial load of German cockroach (Blattella germanica) found in hospital environment. Pathog Glob Health [Internet]. 2014 [cited 2019 Aug 1];108(3):141-7. Available from: https://www.ncbi.nlm.nih.gov/pmc/artic les/PMC4083176/pdf/pgh-108-03-141.pdf

32. World Health Organization, WHO. Burden of Foodborne diseases in the South-East Asia Region [Internet]. World Health Organization Regional Office for SouthEast Asia, editor. Communicable diseases: a global perspective. WHO Library Cataloguing-in-Publication data; 2017 [cited 2019 Aug 2]. 109-124 p. Available from:

http://www.searo.who.int/about/admini stration_structure/cds/burden-offoodborne-sear.pdf

33. World Health Organization. Section 6: Features of important foodborne diseases. In: Foodborne Disease Outbreaks: Guidelines for Investigation and Control [Internet]. WHO Library Cataloguing in Publication Data; 2008 [cited 2019 Aug 2]. p. 54-93. Available from: http://www. who.int/foodsafety/publicati ons/foodborne_disease/Section_6.pdf

34. Moher D, Liberati A, Tetzlaff J, Altman DG. Preferred reporting items for systematic reviews and meta-analyses: the PRISMA statement [Internet]. Vol. 6, PLOS Medicine. PLOS Medicine; 2009 [cited 2019 Jul 19]. p. 1-6. Available from: https://www.ncbi.nlm.nih.gov/pubmed/1 9621072 